\title{
Leverage Ratios, Industry Norms, and Stock Price Reaction: An Empirical Investigation of Stock-for-Debt Transactions
}

\author{
Robert M. Hull
}

Robert M. Hull is an Associate Professor of Finance at Washburn University.

\begin{abstract}
In this paper, I extend the stock-for-debt research by investigating whether stock value is influenced by how a firm changes its leverage ratio in relationship to its industry leverage ratio norm. I find that announcement-period stock returns for firms moving "away from" industry debt-to-equity norms are significantly more negative than returns for firms moving "closer to" these norms. This finding is consistent with optimal capital structure theory if industry debt-toequity norms are reasonable approximations of wealth-maximizing leverage ratios.
\end{abstract}

The event study research of security offerings has largely failed to explore how stock prices react when a firm changes its debt-to-equity ratio (DE) in relationship to its industry DE norm. ${ }^{1}$ This lack of serious regard by event studies for the role of an industry DE benchmark is puzzling given the insight of financial leverage ratio research. This line of research suggests that an industry DE benchmark should prove useful in predicting the direction and magnitude of stock returns that accompany pure leverage-change announcements.

In this paper, I am motivated by the notion that an industry DE norm (e.g., median or mean) is a useful benchmark when investors evaluate a stock's true worth. The research hypothesis is that firms moving "closer to" industry DE benchmarks should have a market response that is positive when compared to firms moving "away from" industry DE benchmarks. To test this hypothesis, I obtain a working sample of 338 observations where firms announce public common stock offerings. This sample is distinctive in two respects that are important for achieving the research aim.

First, it is distinctive in that the sole purpose of each offering is for debt reduction. Not only are the productive assets not directly altered, but simultaneously

${ }^{1}$ As discussed later, an exception is Billingsley, Smith, and Lamy (1994), who focus their examination upon firms that simultaneously issue equity and debt. changing both equity and debt produces a large alteration in a firm's DE. Given the notion that firms operate within target DE ranges, large movements in DEs may be required to detect if the market reacts consistently with the view that an industry DE benchmark is a wealth-maximizing target.

Second, the sample is distinctive in its size $(n=338)$. Despite the support by leverage ratio research for the importance of an industry DE benchmark, one can argue that an industry benchmark DE may not always be a good estimate of what is perceived as its wealthmaximizing DE. Consequently, a large sample offers the possibility of overcoming estimation problems if one can assume that errors in estimating become less of a concern as the sample size increases.

In support of the research hypothesis, I find that the three-day mean cumulative abnormal return (CAR) of $-1.91 \%$ for "closer to" firms is less negative than the $-3.41 \%$ CAR found for "away from" firms. ${ }^{2}$ The

${ }^{2}$ Pure-leverage-decrease studies consisting largely of stockfor-debt transactions (e.g., Masulis, 1983; Finnerty, 1985; Cornett and Travlos, 1989; Copeland and Lee, 1991; Hull, 1994; and Shah, 1994) generally argue that negative CARs arise from negative signaling effects resulting from information asymmetry between insiders and outsiders. More recently, the research offers evidence that the magnitude of the negative CAR is determined by firm size (Hull, Mazachek, and Ockree, 1998) and issue costs (Hull and Kerchner, 1996). 
difference of $1.50 \%$ between the two CARs is statistically significant at the 0.01 level. Even if industry DE norms are not precise approximations of optimal DEs, the significant CAR difference indicates that industry DEs are perceived by the market as desirable DEs. In further support of the research hypothesis, I conduct other tests (in particular, regression analysis) that show the robustness of the findings concerning the importance of an industry DE norm.

I organize the remainder of the paper as follows. Section I reviews the literature, while Section II describes the sample, "change in DE" measurement, summary statistics, methodology, and statistical tests. I report empirical results in Section III and summarize the findings in Section IV.

\section{Literature Review}

In this section, I review capital structure theory and prior empirical research. ${ }^{3}$ I find that a firm's industry DE norm is usable in empirical tests as a benchmark to generate stock price predictions.

\section{A. Capital Structure Models}

The capital structure model of Modigliani and Miller (1963) posits that a firm's value increases as its DE increases due to a corporate tax shield effect. Extensions (e.g., Kraus and Litzenberger, 1972; Jensen and Meckling, 1976; DeAngelo and Masulis, 1980; Kim, 1982; Ross, 1985; and Leland, 1994) argue that an increasing DE leads to ever rising leverage-related costs such that firm value will eventually stop increasing. Dynamic optimal models, such as Fischer, Heinkel, and Zechner (1989) and Mauer and Triantis (1994), do not advocate a static optimal capital structure. Nonetheless, the optimal dynamic financing policy is still characterized by a tradeoff between the corporate tax shield advantage of debt and the leverage-related costs of debt.

Asymmetric information signaling models posit different levels of information between insiders and outsiders such that insider behavior conveys information about firm value to outsiders. These models predict that a change in a firm's mix of debt and equity contains news about stock value. For example, Leland and Pyle (1977) argue that security offering announcements will lead to stock returns that are

${ }^{3}$ See Harris and Raviv (1991) for a comprehensive review of capital structure theory and evidence. See Pinegar and Wilbricht (1989) for a survey of what managers think about capital structure theory. See Howe and Shen (1998) and Laux, Starks, and Yoon (1998) for recent research dealing with the interrelated behavior between a firm and its industry competitors. See Johnson (1997) for recent research on the impact of bank debt on the optimal mix of debt and equity. positively related to the expected change in insider ownership proportions. Ross (1977) claims that leverage increases convey positive news concerning the firm's capacity to service a larger amount of debt. Similarly, it can be argued that leverage decreases signal negative news. Fama (1985) asserts that firms announcing bank debt agreements signal positive news. This is because bankers are privy to inside information and would not approve the loan if negative news was gotten in the lending process. Similarly, firms that announce bank debt reductions convey unfavorable inside information via banker actions. Adverse selection signaling theorists (Myers and Majluf, 1984; and Lucas and McDonald, 1990) posit that the market suspects stock overvaluation when managers announce a stock offering. The negative signaling perceived by outsiders can be lessened if there is a reduced information advantage to insiders.

\section{B. Prior Empirical Research}

Early empirical financial leverage ratio research (e.g., Schwartz and Aronson, 1967; and Scott, 1972) finds similarities in financial leverage ratios within industries and persistent differences across industries. This suggests that the average DE for an industry serves as a unique norm or target for firms within that industry. Subsequent researchers (e.g., Taggart, 1977; and Marsh, 1982) indicate that managers strive toward target DEs while still attempting to time offerings to coincide with favorable market conditions. In general, the earlier leverage ratio research views a target $\mathrm{DE}$ as implying some sort of wealth-maximizing DE that is consistent with the existence of an optimal DE.

The ensuing leverage ratio research reenforces the idea that industry DE norms are reasonable approximations of optimal DEs. For example, Bowen, Daley, and Huber (1982) discover that industry average leverage ratios are stable over time and firms gravitate toward such ratios as if these ratios are optimal. They suggest that a firm's industry average book value of debt to market-based equity ratio is a valid proxy for an optimal leverage ratio. Using the market value of equity in their leverage ratio, Bradley, Jarrell, and Kim (1984) offer additional evidence that leverage ratios within industries are similar, while those across industries are different. Fischer, Heinkel, and Zechner (1989) use debt to market value of equity ratios in their empirical tests when documenting support for optimal models in a dynamic setting. Using debt to market value of equity ratios in their analysis, Billingsley, Smith, and Lamy (1994) show that firms issuing equity and debt simultaneously have more favorable announcement-period stock returns than firms issuing just equity or just debt. They attribute this to the fact that a dual offering of equity and debt makes it easier 
for firms to achieve industry average DEs.

In conclusion, the leverage ratio research suggests that the market views a firm's industry average book value of debt to market value of equity ratio as a wealth maximizing norm. Consequently, a firm's industry DE norm is usable in empirical tests as a benchmark to generate stock price predictions.

\section{Data and Tests}

In this section, I describe the sample, "change in DE" measurement, summary statistics, methodology, and statistical tests. I find that over one-half of the firms in the sample move "away from" their industry DE norms.

\section{A. Sample}

The primary sources of this study's common stock offering announcements are the Investment Dealers' Digest (IDD) and The Wall Street Journal $(W S J) .{ }^{4}$ Major sources used to gather data for descriptive variables and empirical tests include: IDD, WSJ, Compustat Annual Files, Moody's Industrial Manual, CRSP Price and Return Files proxy statements.

The sample contains 338 observations where a firm announces a new common stock issue. Each observation occurs during 1970-1988 and satisfies the following criteria:

1. The sole purpose of the stock offering is to reduce debt.

2. The announcing firm must not be identified as a utility or the transaction as a private swap. ${ }^{5}$

3. Data must be available to calculate stock price behavior for the empirical tests.

4. Data must be obtainable to compute the change in a firm's DE relative to its industry DE norm.

5. An extreme outlier must not result when computing the change in a firm's DE relative to its industry DE norm.

The latter criterion deletes a cluster of ten extreme outliers. ${ }^{6}$ Each outlier is over four standard deviations

${ }^{4}$ Secondary (or less frequently used) sources for initial announcement dates include contact with firms or with investment bankers. When there is disagreement as to the initial date, I use the source with the earliest date.

${ }^{5}$ As detailed by Hand (1989), private swaps are junior-forsenior transactions arranged in the early 1980s and engineered by investment bankers to take advantage of favorable tax rules that applied then.

${ }^{6}$ If not deleted from the sample, the outliers would support the notion that firms moving toward industry DE norms have more positive stock returns compared to those moving away from such norms. This is because the outliers not only have large positive movements toward industry DE norms, but also from the average value calculated for the working sample $(n=338)$.

\section{B. Measuring the Change in the Debt-to- Equity Ratio}

To calculate the change in a firm's DE in relation to its industry DE norm, I begin by considering the following three definitions.

First, "pre-DE" is a firm's debt-to-equity ratio before the initial announcement. I get data for calculating preDEs from the sources that are nearest, yet prior, to the announcement date. "Debt" is all short-term and longterm obligations (bank borrowings, notes, lease obligations, bonds, and so forth) and "equity" is the market value of common stock. ${ }^{7}$

Second, "post-DE" is pre-DE adjusted for the planned changes in the debt and equity. Data for the planned changes in stock and debt come from the sources that announce the stock-for-debt transaction.

Third, "industry DE" is the median DE for an industry. An industry consists of all firms with the same first three digits of their Standard Industrial Classification (SIC) codes. ${ }^{8}$ The SIC codes and other needed information for computing industry DEs are taken from Compustat. When computing an industry DE, I require that there be at least five firms with the same first three digits of their SIC codes. For each firm in an industry, its DE is computed at the end of its fiscal year occurring before the stockfor-debt announcement date. The mean (median) number of firms with data when calculating industry DEs is 46 (28).

Given the above definitions, I define a firm's change in its debt-to-equity ratio relative to its industry DE norm (CDE) as:

$$
\begin{aligned}
\mathrm{CDE}= & \mid \text { Pre-DE }- \text { Industry DE }|-| \text { Post-DE } \\
& - \text { Industry DE } \mid
\end{aligned}
$$

have announcement-period returns that are favorable when compared to the returns of other observations.

${ }^{7}$ The value of common equity is calculated using the stock price the day before the announcement (as given by the CRSP Price Files) times the number of outstanding shares (as given by the source with data closest, yet prior, to the announcement). Both the WSJ and IDD usually give the number of shares outstanding at the time of the announcement. The findings do not depend upon using the nearest source to calculate pre-DE. For example, the reported results are similar if I rely on Compustat (the most distant source).

${ }^{8}$ I use a three-digit SIC code because this gives an industry classification that keeps firms within large industry class sizes. A two-digit classification does not properly distinguish firms based upon actual goods produced while a four-digit classification often leaves industry categories with too few firms to analyze. The 338 observations are not clustered in any particular industry or industries as there are 106 different industries represented. The most observations for any industry are only 18 with the second highest number being 12 . 
where || indicates the absolute value, pre-DE > postDE holds for stock-for-debt transactions, and CDE takes on a negative value only when post-DE is further removed (in absolute terms) from industry DE than is pre-DE.

Figure 1 presents the four cases that exhaust the two ways in which CDE is negative (Cases 1 and 2) and the two ways in which CDE is positive (Cases 3 and 4). There are 150, 47, 95, and 46 observations for Cases 1, 2, 3 and 4, respectively. For Cases 1 and 3, the value for $\mathrm{CDE}$ is simply the difference that results when post-DE is subtracted from pre-DE. CDE is negative in Case 1 since pre-DE and post-DE are both less than industry DE, while it is positive in Case 3 since pre-DE and post-DE are both greater than industry DE. Cases 2 and 4 involve "overshooting" where pre-DE is greater than industry DE and post-DE is less than industry DE.

\section{Summary Statistics}

Table 1 reports summary statistics for two groups: the "away from" group (Cases 1 and 2) and the "closer to" group (Cases 3 and 4). The "away from" group includes those 197 observations that cause the announcing firm's DE to move away from its industry median DE (e.g., CDE is negative). The "closer to" group consists of those 141 observations that cause the announcing firm's DE to move closer to its industry median DE (e.g., CDE is positive).

Panel A in Table 1 gives the frequency distribution by year for the "away from" and "closer to" groups. About one-half of the observations occur between 1980 and 1984. As seen in Panel A, this is also true if I separately inspect either the "away from" group or the "closer to" group. In general, observations for each group are similarly distributed by year.

Panel B in Table 1 reports summary statistics for nine key variables. Statistics for the variables Firm Value, Stock Value, and Offering Value are similar for both groups. Statistics for the two relative size variables, $\triangle$ SHR (the planned proceeds of the offering divided by the pre-announcement market value of common stock) and $\triangle \mathrm{LEV}$ (the planned book value of retired debt divided by firm value), also display similarities when comparing groups. However, the "away from" group consists of firms with lower preDEs, larger industry DEs, and lower post-DEs. The last row of Panel B shows that the "away from" group's mean (median) CDE is -0.17 (-0.13) in contrast to 0.26 $(0.18)$ for the "closer to" group. ${ }^{9}$

${ }^{9}$ Although not reported in table format, I test each of the nine key variables to determine if the mean for the "away from" group is equal to the mean for "closer to" group. Only for the last four variables (Pre-DE, Industry DE, Post-DE, and CDE) do the tests reject the null hypothesis that the means are equal. For each of these four tests, both the standard parametric two-tailed t-statistic and the nonparametric Wilcoxon ranksum z-statistic are significant at the 0.01 level.

\section{Methodology and Tests}

I use the ordinary-least-squares (OLS) market model described by Brown and Warner (1985) when testing whether a portfolio's mean announcement-period abnormal return equals zero. I follow the Scholes and Williams (1977) procedure when calculating the alpha and beta parameters used by the model method. These parameters are computed using the equal-weighted CRSP indices and a comparison period from day +41 to day $+240 .{ }^{10} I$ use the NYSE/AMEX and NASDAQ market indices for respective NYSE/AMEX and OTC firms.

I calculate standard parametric one-tailed t-statistics (for testing the equality of the means of two non-paired samples) when testing the null hypothesis that the mean announcement period abnormal return for the "closer to" group is more negative or equal to the return for the "away from" group. ${ }^{11}$ A positive one-tailed tstatistic that rejects the null hypothesis at the conventional 0.05 level supports the notion that industry DE norms are viewed by market participants as wealth-maximizing targets. To make sure outliers are not driving the results, I also compute nonparametric Wilcoxon rank-sum z-statistics.

For OLS regression tests, I calculate coefficients, tstatistics, $\mathrm{F}$ values, and $\mathrm{R}^{2}$ values. I report one-tailed $\mathrm{t}$-statistics for explanatory variables because each is associated with a capital structure theory that has a definite prediction concerning the sign of its coefficient. $^{12}$

\section{Empirical Results}

In this section, I report empirical results. I find that a firm's movement in relation to its industry DE benchmark is an important factor in determining stock price behavior.

\section{A. Event-Period Return Results}

In Table 2, I provide mean cumulative abnormal stock return (CAR) results for three event periods covering the eleven days surrounding the announcement day (e.g., day 0 ). The three periods are: -5 through $-2,-1$ through +1 , and +2 through +5 . The "total sample"

\footnotetext{
${ }^{10} \mathrm{~A}$ post-announcement estimation period is used because stock issuances frequently follow a period of positive market performance. (This is also true of this study's sample.) I begin with day +41 because the offering date typically occurs by that time. The results are unchanged if I use a 200-day preannouncement estimation period or other methodological variations, including the CRSP value-weighted indices, standard OLS alphas and betas, and other event-period models.

${ }^{11}$ When calculating one-tailed t-statistics, variances are assumed unequal if $\mathrm{F}$ values reject the hypothesis that group variances are equal.

${ }^{12}$ The regression results are robust to other alternate functional forms, including weighted least squares and the White (1980) correction for heteroskedasticity.
} 


\section{Figure 1. Illustration of the Four Cases for CDE}

CDE is a firm's change in its debt-to-equity ratio (DE) relative to its industry DE norm. The horizontal line gives possible post-DE, industry DE, and pre-DE values ranging from 0.2 to 1.2. More details for CDE and definitions for post-DE, industry DE, and pre-DE are given in Section II.B.

CASE 1. CDE is negative and no overshooting occurs. Pre-DE $=0.5 ;$ Industry $D E=0.7 ;$ Post $-D E=0.3$. $C D E=\mid$ Pre-DE - Industry DE $|-|$ Post $-D E-$ Industry $D E|=| 0.5-0.7|-| 0.3-0.7 \mid=-0.2$.

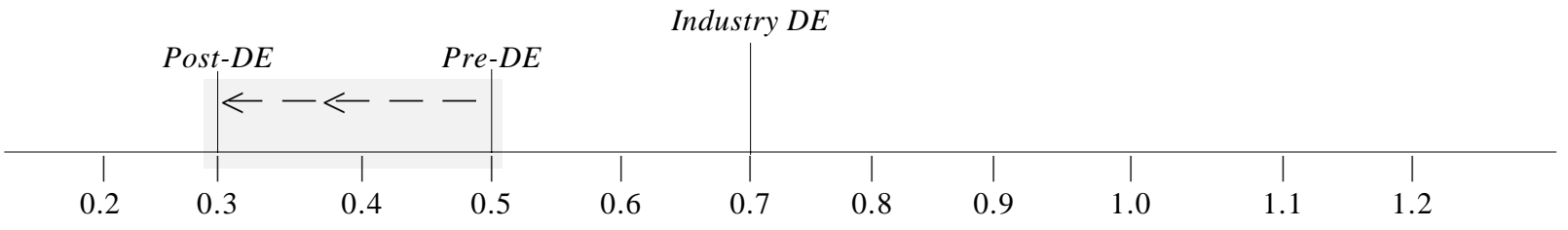

CASE 2. CDE is negative and overshooting occurs. Pre-DE $=0.8 ;$ Industry $\mathrm{DE}=0.7$; Post-DE $=0.5$. $\mathrm{CDE}=\mid$ Pre-DE - Industry DE $|-|$ Post-DE - Industry DE $|=| 0.8-0.7|-| 0.5-0.7 \mid=-0.1$.

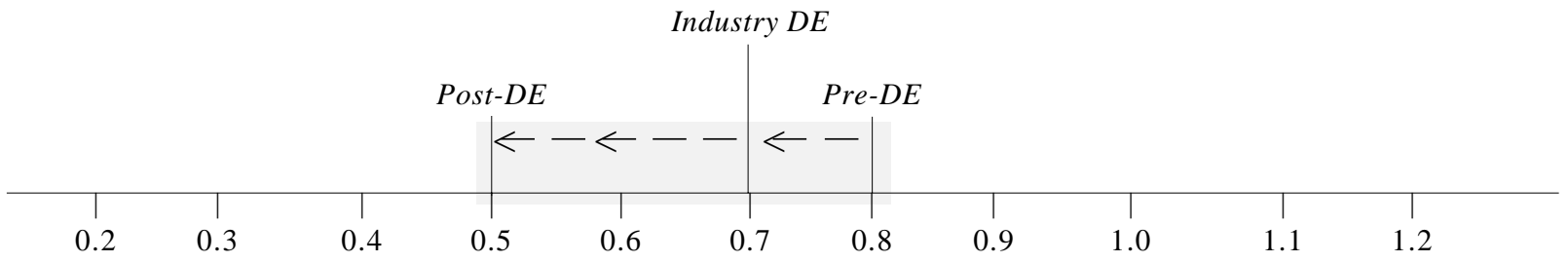

CASE 3. $\mathrm{CDE}$ is positive and no overshooting occurs. Pre-DE $=1.1 ;$ Industry $\mathrm{DE}=0.7$; Post-DE $=0.9$. $\mathrm{CDE}=\mid$ Pre-DE - Industry DE $|-|$ Post-DE - Industry DE $|=| 1.1-0.7|-| 0.9-0.7 \mid=0.2$.

\begin{tabular}{|c|c|c|c|c|c|c|c|c|c|c|}
\hline \multicolumn{11}{|c|}{ Industry $D E$} \\
\hline & & & & & & \multicolumn{3}{|c|}{ Post-DE } & \multicolumn{2}{|c|}{ Pre-DE } \\
\hline & & & & & & & \multicolumn{3}{|c|}{$\leftarrow-\leftarrow--$} & \\
\hline 0.2 & 0.3 & 0.4 & 0.5 & 0.6 & 0.7 & 0.8 & 0.9 & 1.0 & 1.1 & 1.2 \\
\hline
\end{tabular}

CASE 4. $\mathrm{CDE}$ is positive and overshooting occurs. Pre-DE $=0.9$; Industry $\mathrm{DE}=0.7$; Post-DE $=0.6$. $\mathrm{CDE}=\mid$ Pre-DE - Industry DE $|-|$ Post-DE - Industry DE $|=| 0.9-0.7|-| 0.6-0.7 \mid=0.1$.

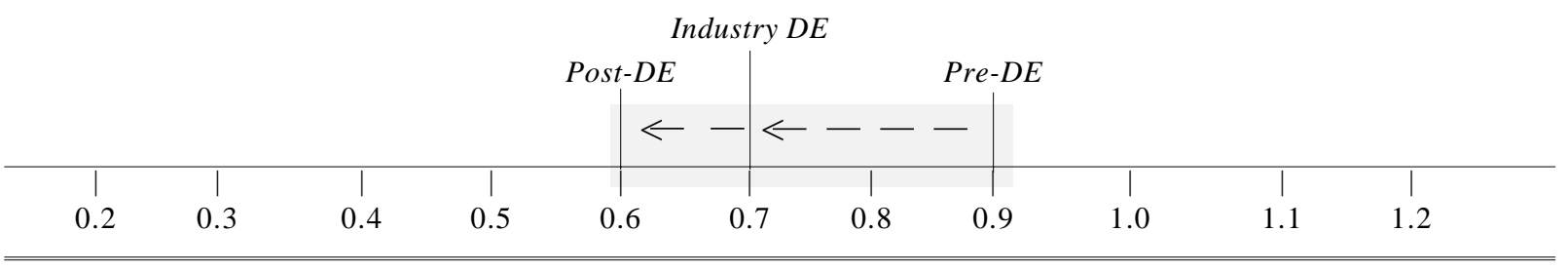

column reveals a three-day $(-1,0,+1)$ announcementperiod CAR of $-2.78 \%$, which is significantly different from zero at the 0.01 level for both the parametric and nonparametric tests. ${ }^{13}$ This column also reports CARs for the two four-day periods surrounding the threeday announcement period. These CARs are not significant except for the nonparametric test for the

${ }^{13}$ I focus on three-day CARs throughout this paper because the abnormal returns for days $-1,0$, and +1 are each negative and significantly different from zero at the 0.01 level. period from days -5 through -2 (the binomial z-statistic of -2.28 is significant at the 0.05 level).

The last three columns of Table 2 report CAR results when testing the "away from" and "closer to" groups. These columns reveal four findings. First, the "closer to" group experiences more volatility (than the "away from" group) if one looks at the two four-day periods surrounding the three-day announcement period. Specifically, the "closer to" group has a negative CAR of $-0.51 \%$ for the four days from -5 through -2 , but a 


\section{Table 1. Summary Statistics}

The sample comprises two groups that contain 338 stock offerings that reduce debt. The "away from" group consists of 197 offerings that move firms away from their industry median debt-to-equity ratios (e.g., CDEs are negative). The "closer to" group is composed of the 141 offerings that move firms closer to their industry median debt-to-equity ratios (e.g., CDEs are positive). Panel A gives the frequency by year for each group. Panel B reports the range (minimum/ maximum), mean, median, and std (standard deviation) for nine key variables. \$M refers to millions of dollars. Firm Value consists of equity (the market value of common stock and any preferred stock as measured by its liquidation value) plus debt (book value of bank borrowings, bonds, lease obligations, and current liabilities). Stock Value is the closing share price the day before the announcement date, multiplied by the number of outstanding common shares as reported by the source closest, yet prior, to the announcement. Offering Value is the expected value of the common stock offering as indicated by the closing share price, the day prior to the announcement date, multiplied by the new (primary) common shares that are planned. $\triangle \mathrm{LEV}$ is the planned book value of retired debt divided by firm value. Values for $\Delta \mathrm{LEV}$ are negative to reflect the decrease in the debt level. $\triangle$ SHR is the planned proceeds of the offering divided by the pre-announcement market value of common stock. Pre-DE, Industry DE, Post-DE, and CDE are defined in Section II.B where I describe the calculation for the change in a firm's debt-to-equity ratio relative to its industry DE norm.

\begin{tabular}{|c|c|c|c|c|c|c|}
\hline \multicolumn{7}{|c|}{ Panel A. Frequency Distribution } \\
\hline Year & "Away & From" Group & $\begin{array}{c}\text { "Closer To" } \\
\text { Group }\end{array}$ & Year & "Away From" Group & "Closer To" Group \\
\hline 1970 & 3 & $(1.5 \%)$ & $4(2.8 \%)$ & 1980 & $31(15.7 \%)$ & $18(12.8 \%)$ \\
\hline 1971 & & $(10.2 \%)$ & $6(4.3 \%)$ & 1981 & $13(6.6 \%)$ & $(7.87 \%)$ \\
\hline 1972 & & $(6.1 \%)$ & $6(4.3 \%)$ & 1982 & $10 \quad(5.1 \%)$ & $(5.7 \%)$ \\
\hline 1973 & 6 & $(3.0 \%)$ & $5(3.5 \%)$ & 1983 & $36(18.3 \%)$ & $20 \quad(14.2 \%)$ \\
\hline 1974 & 4 & $(2.0 \%)$ & $3(2.1 \%)$ & 1984 & $6 \quad(3.0 \%)$ & $9 \quad(6.4 \%)$ \\
\hline 1975 & 7 & $(3.6 \%)$ & $4(2.8 \%)$ & 1985 & $(3.6 \%)$ & $(7.1 \%)$ \\
\hline 1976 & 12 & $(6.1 \%)$ & $9(6.4 \%)$ & 1986 & $(3.6 \%)$ & $(3.5 \%)$ \\
\hline 1977 & 2 & $(1.0 \%)$ & $4(2.8 \%)$ & 1987 & $(3.0 \%)$ & $(7.1 \%)$ \\
\hline 1978 & 9 & $(4.6 \%)$ & $6(4.3 \%)$ & 1988 & $1 \quad(0.5 \%)$ & $(0.7 \%)$ \\
\hline 1979 & 5 & $(2.5 \%)$ & $2(1.4 \%)$ & Total & $197(100.0 \%)$ & $141(100.0 \%)$ \\
\hline
\end{tabular}

Panel B. Nine Key Variables

\begin{tabular}{|c|c|c|c|c|c|c|c|c|}
\hline \multirow[b]{2}{*}{ Variable } & \multicolumn{4}{|c|}{ "Away From" Group } & \multicolumn{4}{|c|}{ "Closer To" Group } \\
\hline & Range & Mean & Median & Std & Range & Mean & Median & Std \\
\hline Firm Value (\$M) & $4 / 16417$ & 706 & 190 & 1600 & $9 / 14662$ & 969 & 195 & 2324 \\
\hline Stock Value (\$M) & $3 / 10902$ & 475 & 144 & 1113 & $4 / 9147$ & 496 & 112 & 1182 \\
\hline Offering Value (\$M) & $0.2 / 640$ & 50.3 & 20.4 & 91.0 & $1.0 / 990$ & 51.9 & 20 & 121 \\
\hline$\Delta \mathrm{LEV}$ & $-37 \% /-0 \%$ & $-8.6 \%$ & $-7.5 \%$ & $5.6 \%$ & $-28 \% /-0 \%$ & $-7.5 \%$ & $-6.2 \%$ & $5.2 \%$ \\
\hline$\Delta$ SHR & $+0 \% / 91 \%$ & $16.1 \%$ & $13.1 \% \%$ & $12.3 \%$ & $0.8 \% / 52 \%$ & $17.4 \%$ & $15.2 \%$ & $11.6 \%$ \\
\hline Pre-DE & $+0.0 / 3.4$ & 0.50 & 0.37 & 0.43 & $0.1 / 4.5$ & 1.10 & 0.83 & 0.82 \\
\hline Industry DE & $+0.1 / 6.5$ & 0.79 & 0.55 & 0.73 & $0.1 / 3.3$ & 0.53 & 0.37 & 0.51 \\
\hline Post-DE & $0.0 / 1.4$ & 0.29 & 0.18 & 0.31 & $+0.0 / 3.7$ & 0.77 & 0.50 & 0.72 \\
\hline $\mathrm{CDE}$ & $-1.2 /-0.0$ & -0.17 & -0.13 & 0.17 & $+0.0 / 1.1$ & 0.26 & 0.18 & 0.23 \\
\hline
\end{tabular}

positive CAR of $+1.30 \%$ for the four days from +2 through +5 . The $+1.30 \%$ CAR is significantly different from zero at the 0.01 and 0.05 levels for the parametric and nonparametric tests. I can find no published events that might account for why "closer to" observations experience significant positive stock price behavior shortly after their initial announcements. The possibility exists that market participants do not always reach an immediate consensus as to the meaning of the news for firms moving "closer to" industry DEs.
Second, the three-day CAR of $-3.41 \%$ for the "away from" group contrasts with the less negative CAR of $-1.91 \%$ for the "closer to" group. As seen in the last column, the $1.50 \%$ difference in three-day CARs between the two groups is significant at the 0.01 level for the parametric test $(\mathrm{t}=2.45)$ and at the 0.05 level for the nonparametric Wilcoxon rank-sum test $(z=2.08)$.

Third, the more favorable market response found for the "closer to" group for days $-1,0$, and +1 continues for the following four days from +2 through +5 . For this four-day period, the "closer to" group has a more 


\section{Table 2. Abnormal Stock Return Results}

The sample comprises two groups that contain 338 stock offerings that reduce debt. The "away from" group consists of 197 offerings that move firms away from their industry median debt-to-equity ratios (e.g., CDEs are negative). The "closer to" group is composed of the 141 offerings that move firms closer to their industry median debt-to-equity ratios (e.g., CDEs are positive). For each cell in the three middle columns, the first row reports the mean abnormal stock return followed by the conventional two-tailed t-statistic (when testing if the return equals zero), while the second row gives the percentage of the sample that has a positive return followed by the two-tailed nonparametric binomial z-statistic (when testing if the percentage equals 50\%). For each cell in the last column, the first row reports the following: the difference when subtracting the mean abnormal stock return for the "away from" group from the mean abnormal return for the "closer to" group; the nonpaired one-tailed parametric t-statistic (when testing the null hypothesis that the mean abnormal stock return for the "closer to" group is more negative or equal to the mean abnormal return for the "away from" group); and, the degrees of freedom. When calculating one-tailed t-statistics, variances are assumed unequal if $F$ values reject the hypothesis that group variances are equal. The second row of the last column reports the $\mathrm{z}$-statistic for the one-tailed nonparametric Wilcoxon rank-sum test.

\begin{tabular}{lcccc}
\hline \hline Event Day(s) & $\begin{array}{c}\text { Total Sample } \\
(\mathbf{n = 3 3 8})\end{array}$ & $\begin{array}{c}\text { "Away From" } \\
\text { Group (n=197) }\end{array}$ & $\begin{array}{c}\text { "Closer To" } \\
\text { Group (n=141) }\end{array}$ & $\begin{array}{c}\text { "Away From" Versus } \\
\text { "Closer To" }\end{array}$ \\
\hline-5 to -2 & $-0.35 \% ;-1.11$ & $-0.23 \% ;-0.62$ & $-0.51 \% ;-0.94$ & $-0.28 \% ;-0.42 ; 266$ \\
& $44 \% ;-2.28 * *$ & $45 \% ;-1.35$ & $42 \% ;-1.93$ & -0.82 \\
& & & & \\
$-1,0,+1$ & $-2.78 \% ;-9.13 * * *$ & $-3.41 \% ;-8.95 * * *$ & $-1.91 \% ;-3.87 * * *$ & $1.50 \% ; 2.45 * * * ; 336$ \\
& $29 \% ;-7.62 * * *$ & $24 \% ;-7.20 * * *$ & $36 \% ;-3.28 * * *$ & $2.08 * *$ \\
& & & \\
& & & \\
& $0.23 \% ; 0.71$ & $-0.53 \% ;-1.23$ & $1.30 \% ; 2.61 * * *$ & $1.83 \% ; 2.77 * * * ; 336$ \\
\end{tabular}

*** Significant at the 0.01 level.

**Significant at the 0.05 level.

favorable CAR that differs by $1.83 \%$ from the CAR for the "away from" group. This $1.83 \%$ difference is significant at the 0.01 level $(\mathrm{t}=2.77$ and $\mathrm{z}=3.00)$. Any market inefficiency that may exist due to a delayed positive market response for "closer to" observations serves to bias the announcement-period tests against supporting the importance of an industry DE benchmark.

Fourth, the 197 "away from" firms have an average stock return of $-3.94 \%$ for a seven-day period consisting of days -1 through +5 . This return is $3.33 \%$ more negative than the seven-day return of $-0.61 \%$ for the 141 "closer to" firms. Adjusting the "closer to" group's return for the negative effects of issue costs, as suggested by Hull and Kerchner (1996), I find a positive (and economically meaningful) return of over $+1.5 \% .{ }^{14}$ Consistent with bankruptcy cost models, this beneficial response may signify that any market fear about the firm's ability to meet obligation to creditors has been resolved. Or, as suggested by agency

\footnotetext{
${ }^{14}$ Hull and Kerchner (1996) examine 323 NYSE/AMEX/OTC stock-for-debt transactions from 1970 to 1989. They find that the negative wealth effect from issue costs as a percentage of outstanding common stock value is $-1.03 \%$ if "cash" expenses (the selling concession and other expenses paid directly to underwriters) are considered. They estimate the negative effect to be about $-2.15 \%$ if both "cash" and "noncash" expenses (underpricing and warrants) are considered. This $-2.15 \%$ is $1.54 \%$ more negative than the $-0.61 \%$ CAR for the "closer to" observations. Thus, adjusting for issue costs could transform a $-0.61 \%$ CAR into a positive CAR greater than $1.5 \%$.
}

theory, this favorable response may reflect a situation where the retired debt had onerous covenants hindering manager-agents from the pursuit of desired investment and dividend policies. Finally, for firms moving "closer to" their industry DE benchmarks, the favorable response indicates the market's approval of their achieving DEs similar to the DEs of their industry competitors.

\section{B. Longer-Term Stock Return Results}

Although not reported in Table 2, I conducted tests to examine stock returns for longer periods. In particular, I looked at the market-adjusted stock price run-up before the initial announcement. The marketadjusted stock price run-up is the cumulative stock return in excess of the cumulative market return (with market returns proxied by the equal-weighted CRSP NYSE/AMEX market index for NYSE/AMEX firms and CRSP OTC market index for OTC firms).

For the period from day -220 through day -2 , the market-adjusted price run-ups of $29.60 \%$ for the "away from" group and $18.64 \%$ for the "closer to" group are both significantly different from zero at the 0.01 level. When comparing the long-run returns between the two groups for this period, I find that the difference of $10.96 \%$ is statistically significant at the 0.01 level $(t=3.11$ and $z=2.96)$. This significant difference suggests that "away from" firms require a greater price run-up before they will stray from their 
industry DE norms. Of noteworthy interest, the $10.96 \%$ greater pre-announcement stock price run-up for the "away from" group is over three times greater than the $3.33 \%$ advantage achieved by the "closer to" group for days -1 through $+5 .{ }^{15}$

I derive three inferences from these longer-term results. First, large stock price run-ups precede stockfor-debt transactions. Similar to prior stock offering research, these transactions appear to be "timed" to capitalize on stock prices that have peaked. Second, if a greater price run-up is needed to induce a stock offering for "away from" firms, then managers of these firms probably experience hesitancy about straying from their industry DE norms. Third, if a smaller price run-up can induce a stock offering for "closer to" firms, then it is likely that managers of these firms are motivated to correct imbalances in DEs. Investors appear to recognize this concern as stock prices for "closer to" firms are not as severely penalized at the time of the announcement.

\section{Other Event-Period Return Results}

Although not reported in table format, I conducted tests to establish the robustness of the three-day CAR findings. The results from these tests are briefly described below.

First, I do a test to overcome the potential bias caused by higher pre-DEs for "closer to" observations as compared to "away from" observations. Higher preDEs raise expectations about issuing equity and reducing debt. If so, the negative announcement-period return for the "closer to" group would have been lessened if already anticipated (and so impounded) in stock prices before the announcement. The greater likelihood of anticipation is consistent with the modified pecking order theory of Myers (1984). This theory predicts that firms with more debt (such as the "closer to" observations) are more likely to use equity to retire debt. This is because financial slack is desirable. To overcome the potential pre-DE bias when comparing CARs for the two groups, I delete 155 observations in the "away from" group with pre-DEs less than 0.7 . This causes the remaining 42 observations to have an average pre-DE slightly greater than the average pre-DE of 1.10 for the 141 "closer to" observations. The three-day CAR for these 42 "away from" observations is $-3.83 \%$ (which is more negative than the $-3.41 \%$ found for all of the 197 "away from" observations). The CAR difference between the 42

\footnotetext{
${ }^{15}$ In contrast to the large stock price run-ups for days -220 to -2 , I find only $1.26 \%$ and $-2.89 \%$ market-adjusted stock price run-ups for the "away from" and "closer to" groups for a comparable period after the announcement. The difference between these two run-ups is not statistically significant $(\mathrm{t}=$ 1.00 and $\mathrm{z}=0.96)$.
}

"away from" and 141 "closer to" observations is significant near the 0.01 and 0.05 levels for the onetailed parametric and nonparametric tests $(\mathrm{t}=2.20$ and $\mathrm{z}=1.82$ ). Thus, if these 155 deletions have overcome any biases suggested by the modified pecking order theory, then the CAR difference is best explained by the notion that industry DE norms are wealthmaximizing DEs. Regardless, ceteris paribus I find no evidence that the CAR difference between groups is explained by different pre-DEs.

Next, I repeat the tests after deleting 59 observations with other firm-specific announcements for event days -3 to +3 . These deletions include 28 observations where the sources disagree about whether all the proceeds are to be used for retiring debt (for example, one source will mention that some proceeds may be used to increase working capital). When comparing three-day CARs for the "away from" and "closer to" groups after deleting these 59 observations, I find parametric and nonparametric one-tailed statistics that are greater than those reported in Table $2(\mathrm{t}=2.50$ and $\mathrm{z}=$ 2.17). Also when comparing CARs between groups, the test statistic values are also greater if the 93 "overshooting" observations are deleted $(\mathrm{t}=3.84$ and $\mathrm{z}$ $=3.47$ ). The greater test statistic values can be attributed to the fact that the 46 overshooting observations in the "closer to" group experience changes in relative size that are more than $40 \%$ greater than the other observations. These 46 observations are predicted to have much larger negative signaling and issue-cost effects.

I next repeat the statistical tests reported in Table 2 using means (instead of medians) to calculate each firm's industry DE. After correcting for outliers, I find that the support for the research hypothesis is even stronger than when using medians. Finally, I conduct tests after adding 169 private swaps to the sample (there are 89 "away from" and 80 "closer to" private swaps). The results are similar when these junior-forsenior transactions are included in the analysis.

\section{Regression Results}

I conduct cross-sectional regression tests to explain announcement period stock returns for the stock-fordebt sample. For this purpose, I use the following regression model:

$$
\begin{aligned}
\mathrm{CAR}= & \mathrm{a}_{0}+\mathrm{a}_{1} \mathrm{COM}+\mathrm{a}_{2} \Delta \mathrm{SHR}+\mathrm{a}_{3} \mathrm{BAN}+\mathrm{a}_{4} \mathrm{RUN} \\
& +\mathrm{a}_{5} \mathrm{IWT}+\mathrm{a}_{6} \mathrm{CDE}+\mathrm{a}_{7} \mathrm{NET}
\end{aligned}
$$

where

$\mathrm{CAR}=$ three-day cumulative abnormal return expressed in decimal form;

$\mathrm{COM}=0$ if not a combination offering, else $1 ;$

$\Delta \mathrm{SHR}=$ the planned proceeds of the offering divided by the pre-announcement 
market value of common stock;

$\mathrm{BAN}=0$ if identified as a bank debt reduction, else 1;

$\mathrm{RUN}=$ the stock price run-up as measured by the cumulative excess return for the period from day -220 to day -2 before the announcement day (values are calculated by adjusting stock returns for market returns as measured by the CRSP equalweighted OTC market index for OTC firms and the CRSP NYSE/AMEX market index for NYSE/AMEX firms);

IWT $=$ stock return standard deviation for days -220 to -21 minus that for days +41 to +240 ;

$\mathrm{CDE}=$ net change in $\mathrm{DE}$ relative to industry median DE as given in Equation (1); and NET $=0$ if CDE negative, else 1 .

The choice of the first five explanatory variables is motivated by the sample's characteristics and prior stock offering research, which suggests that negative CARs are consistent with signaling, agency, and tax effects. The last two variables (CDE and NET) are chosen to capture valuation effects associated with the change in a firm's DE as compared with its industry DE norm.

The Leland and Pyle (1977) signaling model suggests a negative coefficient for COM. The sample contains 77 combination offerings where the secondary sales average about half the amount of the primary component. ${ }^{16}$ The selling of such large quantities of secondary shares indicates that investors with large holdings (such as insiders) are among those selling. Thus, market participants are likely to expect that insiders will be lowering their ownership proportions through combination offerings. COM (or a similar variable) is used in prior studies (e.g., Masulis and Korwar, 1986; Hull and Moellenberndt, 1994; and Hull and Pinches, 1994/1995) that report a significant negative coefficient.

Signaling theory predicts a negative coefficient for $\Delta$ SHR. For example, under the assumption that insiders are not participating in the new offering, Leland and Pyle (1977) hypothesize a negative coefficient for $\Delta$ SHR. This is because greater values for $\Delta$ SHR suggest that insiders are achieving greater decreases in their ownership proportions. Hull and Fortin (1993/ 1994) argue that there will be a greater negative wealth effect due to issue costs for observations with larger $\triangle$ SHR values. Prior studies (e.g., Finnerty, 1985; Asquith and Mullins, 1986; Masulis and Korwar, 1986; and Cornett and Travlos, 1989) use $\Delta$ SHR, or similar relative size variables, and obtain mixed results. ${ }^{17}$

\footnotetext{
${ }^{16} \mathrm{An}$ offering is classified as a combination offering if the primary offering is accompanied by a registered secondary sale that amounts to $10 \%$ or more of the combined primary and secondary components.

${ }^{17}$ For example, I tested the relative size variable, $\triangle \mathrm{LEV}$,
}

Bank debt signaling models (e.g., Bernanke, 1983; and Fama, 1985) suggest a positive coefficient for BAN. If bank debt offerings reflect favorable inside information by bankers, then bank debt reductions should be viewed unfavorably. For the 153 stock offerings that reduce bank debt, investors are likely to believe that these reductions are caused by bankers who want to revise loans unfavorably, or who decline to renew loans. BAN (or a similar variable) is used in prior studies (e.g., Hull and Pinches, 1994/1995; and Hull and Kerchner, 1997) that find a significant positive coefficient. ${ }^{18}$

Adverse-selection theorists (e.g., Myers and Majluf, 1984; and Lucas and McDonald, 1990) predict a negative coefficient for RUN. They suggest that managers will be more inclined to increase equity (or equity-like securities) if they think their equity is overvalued. If the amount of the overvaluation is positively related to a prior stock price run-up, then the negative news (about the equity being overvalued) will become more negative for increasing values of RUN. Consistent with this notion, prior researchers (e.g., Masulis and Korwar, 1986; and Choe, Masulis, and Nanda, 1993) confirm the negative relationship as they generally discover that the market response to a firm's equity announcement is negatively related to its prior stock price run-up. ${ }^{19}$

A negative coefficient for IWT is consistent with the intrasecurity wealth transfer model of Galai and Masulis (1976), which deals with agency costs caused

described in Table 1 as the planned book value of retired debt divided by firm value. For stock-for-debt transactions, more negative values for $\triangle \mathrm{LEV}$ indicate greater decreases in the relative amount of debt. Thus, debt-based models, such as Modigliani and Miller (1963) and Ross (1977), hypothesize a positive coefficient due to lost tax shields and negative signaling, respectively. As expected due to the large correlation between $\triangle \mathrm{SHR}$ and $\triangle \mathrm{LEV}$ (Pearson and Spearman values are -0.65 and -0.74$)$, the results for $\Delta \mathrm{LEV}$ are similar to those results that will later be reported for $\triangle \mathrm{SHR}$.

${ }^{18} \mathrm{Hull}$ and Moellenberndt (1994) delete observations where the debt being retired is not specified as either bank debt or nonbank debt. Like the OTC study by Hull and Pinches (1994/ 1995), I do not delete these observations but assume they reduce nonbank debt. About one-third of the observations in the sample do not specify whether bank debt or nonbank debt will be reduced. Inclusion of these observations in the nonbank debt group can weaken the test for a bank debt signaling effect. Consistent with this notion, Hull and Moellenberndt (1994) obtain stronger support for a bank debt signaling theory than do Hull and Pinches (1994/1995).

${ }^{19}$ Time periods used in prior research (e.g., Asquith and Mullins, 1986; Masulis and Korwar, 1986; Choe, Masulis, and Nanda, 1993; and Hull and Moellenberndt, 1994) to test stock price run-ups are generally similar to ours. Choe, Masulis, and Nanda (1993) argue that any adverse-selection effect will dissipate for a period longer than a year. Hull and Michelson (1999) have recently examined senior-for-junior announcements and found that the relationship between stock price run-ups and announcementperiod returns supports an adverse-selection effect. 
by risk shifting. Positive values for IWT suggest a decrease in risk that implies safer pay-offs especially for senior owners. For a wealth transfer to occur, the safer cash flows to senior owners must come at the expense of residual stock owners. The use of IWT assumes that the change in risk is anticipated at the time of the announcement. Hull and Moellenberndt (1994) use IWT and generally find a significant negative coefficient.

Finally, I expect a positive coefficient for both CDE and NET if industry DE norms are perceived by market participants as desirable DEs. A positive coefficient can be viewed as consistent with optimal capital structure theories if industry DE norms proxy for wealthmaximizing DEs. If so, then the following two explanations can be offered. First, when values for CDE are negative, a positive coefficient can be attributed to a negative tax shield effect (resulting from the debt retirement) and a negative agency effect (as might occur if managers do not participate in the stock offering and thus are less likely to act in the shareholders' interest). Second, when values for CDE are positive, a positive coefficient can be explained by a decrease in bankruptcy costs (stemming from the reduction in excess debt) and by a decrease in agency costs (as might occur when debt with undesirable covenants is retired).

Before conducting regression tests on the total sample and its two groups, I perform several tests that check for multicollinearity among the explanatory variables. To begin with, I calculate correlation coefficients to check if pairs of variables present potential collinearity problems. The results for the total sample are given in Table 3 where I also report the correlation between CAR and each of the seven independent variables used in the regression tests. As expected, because CDE and NET both measure the role of an industry DE norm, the table shows that these two variables should not be used jointly in regression tests (as Pearson and Spearman correlation coefficients are 0.74 and 0.85 ). The only other two independent variables with correlation coefficients greater than 0.20 are COM and RUN. This suggests that I also report results when these variables are used separately. RUN is also significantly correlated (for both the Pearson and Spearman tests) with BAN, CDE, and NET. Thus, firms with greater stock price run-ups are more likely to make combination offers, reduce bank debt, and move away from industry DE norms. Consequently, interpreting the findings for RUN involves some uncertainty. Finally, except for $\Delta$ SHR and IWT, all the explanatory variables have correlation coefficients with CAR that are significant at the 0.05 level or greater.

Although not reported in Table 3, I also conducted correlation tests for the "away from" group and for the "closer to" group. There are only two independent variables for which the Pearson and Spearman correlation coefficients are both greater than 0.20 . These two variables are $\Delta$ SHR and CDE. $\Delta$ SHR is negatively correlated with CDE for the "away from" tests (coefficients range from -0.45 to -0.56 ) but positively correlated with CDE for the "closer to" tests (coefficients range from 0.53 to 0.58 ). Thus, I use these two variables separately when conducting regression tests for the "away from" and "closer to" groups.

Besides correlation tests, I calculate variance inflation factors (VIFs). For all of the reported regression tests, VIFs are typically close to one and never exceed 1.12. As noted by Kennedy (1986), such VIFs are quite small and thus well below conventional levels for indicating multicollinearity.

Table 4 reports regression results. Panel A gives results for tests on the total sample. The first three tests use CDE (as opposed to NET). For the first test, Panel A reports an F value of 6.08 (which is significant at the 0.01 level) and an adjusted $\mathrm{R}^{2}$ value of 0.083. All explanatory variables have the predicted signs with both COM and CDE significant at the 0.01 level $(t=-2.94$ and $t=4.07$, respectively $)$. BAN is marginally significant at the 0.10 level $(\mathrm{t}=$ 1.47). As discussed earlier, since COM and RUN have correlation coefficients greater than 0.20 , I repeat the test twice (by first deleting COM and then omitting RUN). When COM is deleted, the tstatistic for RUN changes to -1.54 becoming marginally significant at the 0.10 level. When I delete RUN, the t-statistic for IWT changes to -1.40 , which is also now marginally significant.

Next, I repeat the latter three tests with NET replacing CDE. Whereas CDE was significant at the 0.01 level, NET is only significant at the 0.05 level. Nonetheless, the significant coefficient for NET reveals that the direction itself of the movement relative to an industry DE norm is a pivotal indicator of how the market will respond to a stock-for-debt transaction. When NET is used, the t-statistics for BAN and RUN increase. When COM is deleted, I find that RUN is significant at the 0.05 level $(t=1.76)$. When RUN is omitted, BAN is significant at the 0.05 level $(\mathrm{t}=1.66)$.

Panel B in Table 4 reports regression results for the "away from" group. As mentioned earlier, the correlation between $\triangle$ SHR and CDE prevents the testing of these two variables together. When $\triangle \mathrm{SHR}$ is deleted from the test, I find that COM and CDE are both significant at the 0.01 level (t-statistics are -3.60 and -2.99 , respectively) and IWT is marginally significant at the 0.10 level $(\mathrm{t}=$ -1.50). When CDE is omitted, COM and $\triangle$ SHR are significant at the 0.01 and 0.05 levels (t-statistics are -3.44 and -1.80 , respectively).

Panel C in Table 4 gives results for the "closer to" group. Once again, the correlation between $\Delta$ SHR and 


\section{Table 3. Pearson and Spearman Correlation Results for 338 Stock Offerings that Reduce Debt}

The Pearson correlation coefficients are reported in the lower left-hand half of the table. The Spearman correlation coefficients are given in the upper right-hand half. The eight variables for which correlation tests are conducted are defined below.

$\mathrm{CAR}=$ three-day cumulative abnormal return expressed in decimal form;

$\mathrm{COM}=0$ if not a combination offering, else 1 ;

$\triangle \mathrm{SHR}=$ the planned proceeds of the offering divided by the pre-announcement market value of common stock;

$\mathrm{BAN}=0$ if identified as a bank debt reduction, else 1 ;

RUN $=$ the stock price run-up as measured by the cumulative excess return for the period from day -220 to day -2 before the announcement day (values are calculated by adjusting stock returns for market returns are measured by the CRSP equal-weighted OTC market index for OTC firms and the CRSP NYSE/AMEX market index for NYSE/AMEX firms);

IWT $=$ stock return standard deviation for days -220 to -21 minus that for days +41 to +240 ;

$\mathrm{CDE}=$ net change in DE relative to industry median DE as given in Equation (1); and

$\mathrm{NET}=0$ if CDE negative, else 1 .

\begin{tabular}{lcccccccc}
\hline \hline & CAR & COM & SSHR & BAN & RUN & IWT & CDE & NET \\
\hline CAR & - & $-0.154 * * *$ & -0.070 & $0.112 * *$ & $-0.176^{* * *}$ & -0.053 & $0.175^{* * *}$ & $0.116^{* * *}$ \\
COM & $-0.179 * * *$ & - & -0.011 & -0.002 & $0.219 * * *$ & -0.027 & -0.060 & -0.088 \\
$\Delta$ SHR & -0.044 & -0.024 & - & -0.100 & 0.095 & -0.056 & -0.007 & 0.068 \\
BAN & $0.104 * *$ & -0.002 & -0.049 & - & $-0.140 * * *$ & -0.071 & 0.103 & 0.082 \\
RUN & $-0.135 * *$ & $0.210 * * *$ & 0.032 & $-0.134 * *$ & - & 0.086 & $-0.149 * * *$ & -0.161 \\
IWT & -0.058 & -0.036 & -0.080 & -0.050 & $0.159 * *$ & - & 0.028 & -0.016 \\
CDE & $0.234 * * *$ & -0.067 & 0.032 & 0.070 & $-0.143 * * *$ & 0.041 & - & $0.854 * * *$ \\
NET & $0.138 * * *$ & -0.088 & 0.055 & 0.082 & $-0.167 * * *$ & -0.044 & $0.740 * * *$ & - \\
& & & & & & & & \\
\hline
\end{tabular}

CDE require separate tests for each variable. When $\triangle$ SHR is eliminated from the test, I find that the only variable that is statistically significant is CDE. It is significant at the 0.01 level $(\mathrm{t}=2.47)$. When $\mathrm{CDE}$ is omitted, I find that RUN is marginally significant at the 0.10 level. I also find that $\triangle$ SHR no longer has a negative coefficient. The results in Panel C together with those in Panel B suggest that $\triangle \mathrm{SHR}$ can capture wealth effects similar to CDE. For example, for "away from" tests, $\triangle$ SHR's negative coefficient indicates that it is capturing negative effects associated with movement away from industry DE norms. For "closer to" tests, $\Delta$ SHR's positive coefficient is consistent with it capturing positive effects associated with movement toward industry DE norms.

Overall, the results in Table 4 show that the movement in a firm's DE in relation to its industry DE norm does the best job of accounting for CARs. Most noticeably, the inclusion of CDE in the regression model substantially increases both the $\mathrm{R}^{2}$ and the $\mathrm{F}$ values. The results also suggest that negative signaling effects related to changes in insider ownership proportions are best detected when firms are moving away from their industry DE norms. The presence of these signaling effects when firms are moving closer to their industry DE norms may be harder to discern because of the positive bankruptcy-agency considerations that appear to be present when firms are moving toward their industry DE norms. Finally, I find some marginal statistical support for bank debt signaling, adverse selection signaling, and an intrasecurity wealth transfer effect.

\section{Summary}

In this study, I extend the pure leverage change research by examining whether the change in a firm's DE relative to its industry DE norm influences the market response to stock-for-debt announcements. Because the leverage ratio research literature suggests that industry DE norms proxy for wealth-maximizing DEs, an important by-product of the research is a simultaneous test of optimal capital structure models. Ceteris paribus, optimal models predict a decrease (an increase) in firm value when a firm moves "away from" ("closer to") its optimal DE. 


\section{Table 4. Regression Results for 338 Stock Offerings that Reduce Debt}

The regression model is: where

$$
\mathrm{CAR}=a_{0}+a_{1} \mathrm{COM}+a_{2} \Delta \mathrm{SHR}+a_{3} \mathrm{BAN}+a_{4} \mathrm{RUN}+a_{5} \mathrm{IWT}+a_{6} \mathrm{CDE}+a_{7} \mathrm{NET}
$$

$\mathrm{CAR}=$ three-day cumulative abnormal return expressed in decimal form;

$\mathrm{COM}=0$ if not a combination offering, else 1 ;

$\triangle \mathrm{SHR}=$ the planned proceeds of the offering divided by the pre-announcement market value of common stock;

$\mathrm{BAN}=0$ if identified as a bank debt reduction, else 1 ;

RUN $=$ is the stock price run-up as measured by the cumulative excess return for the period from day -220 to -2 before the announcement day (values are calculated by adjusting stock returns for market returns as measured by the CRSP equal-weighted OTC market index for OTC firms and the CRSP NYSE/AMEX market index for NYSE/AMEX firms);

IWT $=$ stock return standard deviation for days -220 to -21 minus that for days +41 to +240 ;

$\mathrm{CDE}=$ net change in DE relative to industry median DE as given in Equation (1); and

$\mathrm{NET}=0$ if CDE negative, else 1.

For the first eight columns, the first row reports estimated coefficients and the second row gives OLS t-statistics. Except for the Constant column, the t-test is one-tailed because each explanatory variable has a definite prediction concerning the sign of its coefficient.

\begin{tabular}{|c|c|c|c|c|c|c|c|c|c|}
\hline $\begin{array}{c}\text { Constant } \\
a_{0}\end{array}$ & $\begin{array}{c}\text { COM } \\
a_{1}\end{array}$ & $\begin{array}{c}\Delta \mathrm{SHR} \\
\mathrm{a}_{2} \\
\end{array}$ & $\begin{array}{c}\text { BAN } \\
a_{3}\end{array}$ & $\begin{array}{c}\text { RUN } \\
a_{4} \\
\end{array}$ & $\begin{array}{c}\text { IWT } \\
a_{5} \\
\end{array}$ & $\begin{array}{c}\text { CDE } \\
\mathrm{a}_{6}\end{array}$ & $\begin{array}{c}\text { NET } \\
a_{7} \\
\end{array}$ & F-Value & $\begin{array}{c}\text { Adjusted } \\
\mathbf{R}^{2} \\
\end{array}$ \\
\hline \multicolumn{10}{|c|}{ Panel A. Total Sample $(n=338)$} \\
\hline $\begin{array}{l}-0.021 \\
(-3.14)^{* * *}\end{array}$ & $\begin{array}{l}-0.021 \\
(-2.94)^{* * *}\end{array}$ & $\begin{array}{c}-0.026 \\
(-1.04)\end{array}$ & $\begin{array}{c}0.009 \\
(1.47)^{*}\end{array}$ & $\begin{array}{c}-0.009 \\
(-0.89)\end{array}$ & $\begin{array}{c}-0.467 \\
(-1.23)\end{array}$ & $\begin{array}{l}0.042 \\
(4.07)^{* * *}\end{array}$ & - & $6.08 * * *$ & 0.083 \\
\hline $\begin{array}{l}-0.025 \\
(-3.67)^{* * *}\end{array}$ & - & $\begin{array}{c}-0.023 \\
(-0.92)\end{array}$ & $\begin{array}{c}0.008 \\
(1.36)^{*}\end{array}$ & $\begin{array}{c}-0.015 \\
(-1.54)^{*}\end{array}$ & $\begin{array}{r}-0.387 \\
(-1.01)\end{array}$ & $\begin{array}{l}0.043 \\
(4.12)^{* * *}\end{array}$ & - & $5.44 * * *$ & 0.062 \\
\hline $\begin{array}{l}-0.023 \\
(-3.64)^{* * *}\end{array}$ & $\begin{array}{l}-0.023 \\
(-3.21)^{* * *}\end{array}$ & $\begin{array}{c}-0.027 \\
(-1.08)\end{array}$ & $\begin{array}{c}0.009 \\
(1.56)^{*}\end{array}$ & - & $\begin{array}{c}-0.526 \\
(-1.40)^{*}\end{array}$ & $\begin{array}{l}0.043 \\
(4.22)^{* * *}\end{array}$ & - & $7.15^{* * *}$ & 0.084 \\
\hline $\begin{array}{l}-0.026 \\
(-3.53)^{* * *}\end{array}$ & $\begin{array}{l}-0.021 \\
(-2.91)^{* * *}\end{array}$ & $\begin{array}{c}-0.024 \\
(-0.96)\end{array}$ & $\begin{array}{c}0.009 \\
(1.52)^{*}\end{array}$ & $\begin{array}{r}-0.011 \\
(-1.12)\end{array}$ & $\begin{array}{r}-0.351 \\
(-0.91)\end{array}$ & & $\begin{array}{c}0.012 \\
(1.99)^{* *}\end{array}$ & $3.87 * * *$ & 0.049 \\
\hline $\begin{array}{l}-0.030 \\
(-4.09)^{* * *}\end{array}$ & - & $\begin{array}{c}-0.022 \\
(-0.086)\end{array}$ & $\begin{array}{c}0.009 \\
(1.42)^{*}\end{array}$ & $\begin{array}{c}-0.017 \\
(-1.76)^{* *}\end{array}$ & $\begin{array}{l}-0.267 \\
(-0.68)\end{array}$ & - & $\begin{array}{l}0.013 \\
(2.13)^{* *}\end{array}$ & $2.89 * * *$ & 0.027 \\
\hline $\begin{array}{l}-0.029 \\
(-4.20)^{* * *} \\
\end{array}$ & $\begin{array}{l}-0.023 \\
(-3.22)^{* * *} \\
\end{array}$ & $\begin{array}{c}-0.026 \\
(-1.02) \\
\end{array}$ & $\begin{array}{l}0.010 \\
(1.66)^{* *}\end{array}$ & & $\begin{array}{l}-0.423 \\
(-1.11)\end{array}$ & & $\begin{array}{c}0.013 \\
(2.17)^{* * *}\end{array}$ & $4.39 * * *$ & 0.048 \\
\hline \multicolumn{10}{|c|}{ Panel B. "Away From" Group $(n=197)$} \\
\hline $\begin{array}{l}-0.017 \\
(-2.19)^{* *}\end{array}$ & $\begin{array}{l}-0.030 \\
(-3.60)^{* *}\end{array}$ & & $\begin{array}{c}0.009 \\
(1.18)\end{array}$ & $\begin{array}{l}-0.05 \\
(-0.39)\end{array}$ & $\begin{array}{c}-0.777 \\
(-1.50)^{*}\end{array}$ & $\begin{array}{l}0.066 \\
(2.99)^{* * * *}\end{array}$ & & $4.87 * * *$ & 0.090 \\
\hline $\begin{array}{l}-0.022 \\
(-2.58)^{* * *} \\
\end{array}$ & $\begin{array}{l}-0.029 \\
(-3.44)^{* * *} \\
\end{array}$ & $\begin{array}{l}-0.056 \\
(-1.80)^{* *}\end{array}$ & $\begin{array}{r}0.009 \\
(1.20) \\
\end{array}$ & $\begin{array}{c}-0.001 \\
(-0.06) \\
\end{array}$ & $\begin{array}{c}-0.704 \\
(-1.33)^{*} \\
\end{array}$ & - & & $3.64 * * *$ & 0.063 \\
\hline \multicolumn{10}{|c|}{ Panel C. "Closer To" Group $(n=141)$} \\
\hline $\begin{array}{l}-0.035 \\
(-3.29)^{* * *}\end{array}$ & $\begin{array}{l}-0.004 \\
(-0.32)\end{array}$ & - & $\begin{array}{c}0.012 \\
(1.17)\end{array}$ & $\begin{array}{l}-0.020 \\
(-1.24)\end{array}$ & $\begin{array}{c}-0.131 \\
(-0.23)\end{array}$ & $\begin{array}{l}0.054 \\
(2.47)^{* * *}\end{array}$ & - & $2.18^{*}$ & 0.040 \\
\hline $\begin{array}{l}-0.022 \\
(-1.83)^{*}\end{array}$ & $\begin{array}{r}0.006 \\
(-0.42)\end{array}$ & $\begin{array}{c}0.014 \\
(0.31)\end{array}$ & $\begin{array}{c}0.012 \\
(1.15)\end{array}$ & $\begin{array}{l}-0.025 \\
(1.15)\end{array}$ & $\begin{array}{c}-0.370 \\
(-0.06)\end{array}$ & - & - & 0.93 & 0.003 \\
\hline
\end{tabular}

\footnotetext{
***Significant at the 0.01 level.

$* *$ Significant at the 0.05 level.

*Significant at the 0.10 level.
}

The sample consists of 197 common stock-for-debt transactions where the announcing firm's DE moves "away from" its industry median DEs, and 141 transactions where the DE moves "closer to" its industry median DEs. I find an average announcement period return of $-3.41 \%$ for the "away from" group, and a $-1.91 \%$ return for the "closer to" group. The research hypothesis is supported because the parametric and nonparametric tests show that the $1.50 \%$ difference in returns between the "away from" and "closer to" groups is significant at the 0.01 level. To the extent industry DE norms represent optimal DEs, the significant return difference between groups is consistent with optimal capital structure models that emphasize the tradeoff between positive and negative leverage-related effects. 
I do other tests that include time frames longer than the three-day announcement period. For tests that include a seven-day period, I offer evidence that the 141 "closer to" firms have a positive market reaction. I also analyze stock price behavior for days -220 through -2 and find that "away from" firms achieve a $10.96 \%$ greater cumulative excess return than "closer to" firms. This $10.96 \%$ return is more than three times the $3.33 \%$ return advantage achieved by the "closer to" group for days -1 through +5 . Lastly, I conduct regression tests using variables previously tested in stock-for-debt research along with two variables, CDE and NET, that represent the firm's change in its DE relative to its industry median DE. Both variables are statistically significant. CDE is statistically significant at the 0.01 level for all of the tests. Most important, the inclusion of CDE in the regression model substantially increases both

\section{References}

Asquith, P. and D. Mullins, Jr., 1986, "Equity Issues and Offering Dilution," Journal of Financial Economics (JanuaryFebruary), 61-89.

Bernanke, B., 1983, "Non-Monetary Effects of the Financial Crisis in the Propagation of the Great Depression," American Economic Review (June), 257-276.

Billingsley, R., D. Smith, and R. Lamy, 1994, "Simultaneous Debt and Equity Issues and Capital Structure Targets," Journal of Financial Research (Winter), 495-516.

Bowen, R., L. Daley, and C. Huber, 1982, "Leverage Measures and Industrial Classification: Review and Additional Evidence," Financial Management (Winter), 10-20.

Bradley, M., G. Jarrell, and E. Kim, 1984, "On the Existence of an Optimal Capital Structure: Theory and Evidence," Journal of Finance (September), 857-878.

Brown, S. and J. Warner, 1985, "Using Daily Stock Returns," Journal of Financial Economics (March), 3-31.

Choe, H., R. Masulis, and V. Nanda, 1993, "Common Stock Offerings across the Business Cycle," Journal of Financial Economics (February), 3-31.

Copeland, T. and W. Lee, 1991, "Exchange Offers and Stock Swaps--New Evidence," Financial Management (Autumn), 34-48.

Cornett, M. and N. Travlos, 1989, "Information Effects Associated with Debt-for-Equity and Equity-for-Debt Exchange Offers," Journal of Finance (June), 451-468.

DeAngelo, H. and R. Masulis, 1980, "Optimal Capital Structure under Corporate and Personal Taxation, "Journal of Financial Economics (March), 3-30.

Fama, E., 1985, “What's Different about Banks?” Journal of Monetary Economics (January), 29-39. the $\mathrm{R}^{2}$ and the $\mathrm{F}$ values. All of the regression results for CDE also hold if I separately test either the "away from" group (where CDE values are all negative) or the "closer to" group (where CDE values are all positive).

Although it may be an unachievable task to estimate precisely the DE that maximizes a firm's value, this study has shown that the market's reaction to leveragedecrease announcements depends on how a firm's DE changes relative to its industry DE norm. Future research should continue to explore the role of an industry DE norm when assessing the market reaction to security-offering announcements. In closing, the empirical evidence that I offer should not be totally surprising to academicians and financial executiveswho, for many years, have used euphemisms such as "target," "industry average," "optimum," or "relevant" to convey their belief in a wealth-maximizing debt level.

Finnerty, J., 1985, "Stock-for-Debt Swaps and Shareholder Returns," Financial Management (Autumn), 5-17.

Fischer, E., R. Heinkel, and J. Zechner, 1989, "Dynamic Capital Structure Choice: Theory and Tests," Journal of Finance (March), 19-40.

Galai, D. and R. Masulis, 1976, "The Option Pricing Model and the Risk Factor of Stock," Journal of Financial Economics (January/March), 53-81.

Hand, J., 1989, “Did Firms Undertake Debt-Equity Swaps for an Accounting Paper Profit or True Financial Gain?" Accounting Review (October), 587-623.

Harris, M. and A. Raviv, 1991, "The Theory of Capital Structure," Journal of Finance (March), 297-355.

Howe, S. and Y. Shen, 1998, "Information Associated with Dividend Initiations: Firm-Specific or Industry-Wide?" Financial Management (Autumn), 17-26.

Hull, R., 1994, "Stock Price Behavior of Pure Capital Structure Issuance and Cancellation Announcements," Journal of Financial Research (Fall), 439-448.

Hull, R. and R. Fortin, 1993/1994, "Issuance Expenses and Common Stock Offerings for Over-the-Counter Firms," Journal of Small Business Finance (No. 1), 1-17.

Hull, R. and R. Kerchner, 1996, "Issue Costs and Common Stock Offerings," Financial Management (Winter), 54-66.

Hull, R. and R. Kerchner, 1997, "Pure Leverage Decreases: A Study of Two Junior-for-Senior Groups," Quarterly Journal of Business and Economics (Winter), 51-68.

Hull, R., J. Mazachek, and K. Ockree, 1998, "Firm Size, Common Stock Offerings, and Announcement Period Returns," Quarterly Journal of Business and Economics (Summer), 3-24. 
Hull, R. and S. Michelson, 1999, "The Information Contents of Senior Offerings that Reduce Junior Securities," Quarterly Review of Economics and Finance, forthcoming.

Hull, R. and R. Moellenberndt, 1994, "Bank Debt Reduction Announcements and Negative Signaling," Financial Management (Summer), 21-30.

Hull, R. and G. Pinches, 1994/1995, "Firm Size and the Information Contents of Over-the-Counter Common Stock Offerings," Journal of Small Business Finance (No. 1), 31-56.

Jensen, M. and W. Meckling, 1976, "Theory of the Firm: Managerial Behavior, Agency Costs and Ownership Structure," Journal of Financial Economics (October), 305-360.

Johnson, S., 1998, "The Effect of Bank Debt on Optimal Capital Structure," Financial Management (Spring), 47-56.

Kennedy, P., 1986, A Guide to Econometrics, Cambridge, MA, MIT Press.

Kim, E., 1982, “Miller's Equilibrium, Shareholder Leverage Clienteles, and Optimal Capital Structure," Journal of Finance (May), 301-320.

Kraus, A. and R. Litzenberger, 1973, “A State-Preference Model of Optimal Financial Leverage," Journal of Finance (September), 911-922.

Laux, P., L. Starks, and P. Yoon, 1998, "The Relative Importance of Competition and Contagion in IntraIndustry Information Transfers: An Investigation of Dividend Announcements," Financial Management (Autumn), 5-16.

Leland, H., 1994, "Corporate Debt Value, Bond Covenants, and Optimal Capital Structure," Journal of Finance (September), 1213-1252.

Leland, H. and D. Pyle, 1977, "Informational Asymmetries, Financial Structure, and Financial Intermediation," Journal of Finance (May), 371-388.

Lucas, D. and R. McDonald, 1990, "Equity Issues and Stock Price Dynamics," Journal of Finance (September), 1019-1044.

Marsh, P., 1982, "The Choice between Equity and Debt: An Empirical Study," Journal of Finance (March), $121-144$.

Masulis, R., 1983, "The Impact of Capital Structure Change on Firm Value: Some Estimates," Journal of Finance (March), 107-126.
Masulis, R. and A. Korwar, 1986, "Seasoned Equity Offerings: An Empirical Investigation," Journal of Financial Economics (January/February), 91-118.

Mauer, D. and A. Triantis, 1994, "Interactions of Corporate Financing and Investment Decisions: A Dynamic Framework," Journal of Finance (September), 12531278.

Modigliani, F. and M. Miller, 1963, "Corporate Income Taxes and the Cost of Capital," American Economic Review (June), 433-443.

Myers, S., 1984, "The Capital Structure Puzzle," Journal of Finance (July), 575-592.

Myers, S. and N. Majluf, 1984, "Corporate Financing and Investment Decisions when Firms Have Information that Investors Do Not Have," Journal of Financial Economics (June), 187-221.

Pinegar, J. and L. Wilbricht, 1989, "What Managers Think of Capital Structure Theory: A Survey," Financial Management (Winter), 82-91.

Ross, S., 1977, "The Determination of Financial Structure: The Incentive-Signaling Approach," Bell Journal of Economics (Spring), 23-40.

Ross, S., 1985, "Debt and Taxes and Uncertainty," Journal of Finance (July), 637-658.

Scholes, M. and J. Williams, 1977, "Estimating Betas from Nonsynchronous Data," Journal of Financial Economics (December), 309-328.

Schwartz, E. and J. Aronson, 1967, "Some Surrogate Evidence in Support of the Concept of Optimal Financial Structure," Journal of Finance (March), 10-18.

Scott, D., 1972, "Evidence on the Importance of Financial Structure," Financial Management (Spring), 45-50.

Shah, K., 1994, "The Nature of Information Conveyed by Pure Capital Structure Changes," Journal of Financial Economics (August), 89-127.

Taggart, R., 1977, "A Model of Corporate Financing Decisions," Journal of Finance (December), 1467-1484.

White, H., 1980, “A Heteroskedasticity-Consistent Covariance Matrix Estimator and a Direct Test for Heteroskedasticity," Econometrica (May), 817-838. 